\title{
Laminated lake sediments in northeast Poland: distribution, preconditions for formation and potential for paleoenvironmental investigation
}

\author{
Wojciech Tylmann • Bernd Zolitschka • \\ Dirk Enters • Christian Ohlendorf
}

Received: 9 January 2013/Accepted: 7 August 2013/Published online: 23 August 2013

(C) The Author(s) 2013. This article is published with open access at Springerlink.com

\begin{abstract}
Glacial landscapes of the Land of Great Masurian Lakes and Suwałki Lakelands in northeast Poland are characterized by very high abundance of lakes. These two areas were surveyed for lakes containing laminated sediments. Using bathymetry as a criterion, 60 small, deep lakes, representing preferred conditions for formation and preservation of lacustrine non-glacial varves, were selected for gravity coring. We found laminated sediments in 24 of the lakes, 15 in the Land of Great Masurian Lakes and 9 in the Suwałki Lakeland. Seven of these 24 sediment records were laminated in the topmost part only. Analysis of lake morphometric variables showed that the relation between surface area and maximum water depth can be used to identify lakes with laminated sediments. Most of the newly discovered lakes with laminated deposits have surface areas $\leq 0.3 \mathrm{~km}^{2}$ and maximum depths of 15-35 m. Multivariate statistical analysis (Linear Discriminant Analysis) of the lake dataset identified the morphological features of lake basins and their catchments that largely control preservation of laminated sediments. Microscopic
\end{abstract}

\footnotetext{
W. Tylmann $(\square)$

Department of Geomorphology and Quaternary Geology, Institute of Geography, University of Gdańsk,

Bażyńskiego 4, 80952 Gdańsk, Poland

e-mail: geowt@ug.edu.pl

B. Zolitschka $\cdot$ D. Enters · C. Ohlendorf GEOPOLAR, Institute of Geography, University of Bremen, Celsiusstr. FVG-M, 28359 Bremen, Germany
}

and geochemical analyses revealed a biogenic (carbonaceous) type of lamination typical for lakes in northeast Poland. Such lakes are characterized by a spring-summer lamina that is rich in calcium carbonate and an autumn-winter lamina composed of organic and minerogenic detritus. This pattern may be modified by multiple periods of calcite deposition during a single year or substantial contribution of clastic material. Laminations and high sedimentation rates offer the possibility of high-resolution investigation of past climate and environmental changes through application of myriad biological, isotopic and geochemical proxies.

Keywords Laminae formation - Varves . Biogenic lamination · Lake morphometry $\cdot$ Land of Great Masurian Lakes · Suwałki Lakeland

\section{Introduction}

High-resolution investigations of climate change and human impact on ecosystems are currently among the most common studies in environmental research. With the increasing number of investigations of lacustrine sediment profiles, it is evident that these are key archives that provide reliable information about past climate and environmental changes (Ojala and Alenius 2005; Tomkins et al. 2008; Corella et al. 2011). Invaluable in this respect are annually laminated (varved) sediments, which are not only a source of 
proxy data for tracking ecosystem response to climate change (Randsalu Wendrup et al. 2012) or for quantitative palaeoclimatic reconstruction (Larocque-Tobler et al. 2010), but enable precise dating at annual resolution (Zolitschka 2007).

Laminated sediments are preserved in lakes in different environmental settings over a broad geographic range (Ojala et al. 2012). Two fundamental requirements for the development of laminations in lacustrine sediments are: (1) seasonal variations in biological activity, chemical processes and terrestrial input, causing changes in sediment composition, and (2) appropriate conditions for preservation of the laminae. Strong climatic seasonality is most commonly responsible for variations in sediment composition, including both clastic and biogenic components (Zolitschka 2007). Laminae preservation is favoured in lakes with anoxic bottom waters where bioturbation is negligible or absent. Therefore, laminations are often found in sediments of small, deep lakes that have a permanently stratified water column (Anderson et al. 1985; Saarnisto 1986; Tylmann et al. 2012), and in dimictic lakes in which the laminated structure is preserved because of high primary productivity that reduces oxygen in near-bottom waters during decomposition (Simola 1979; Renberg and Segerström 1981). Intra-annual changes of redox conditions within the deep lake waters, resulting in seasonal precipitation of iron hydroxides or iron sulphides, may also contribute to laminae formation (Renberg 1981; Tomkins et al. 2009). There is, however, no simple criterion to explain the occurrence of laminations because the conditions for formation and preservation are complex and include a large number of factors. Moreover, laminae formation may vary through time because of changing climatic and limnological conditions (Brauer 2004). These changes, including human influence, can interrupt laminated sequences or initiate the formation of laminated sediments.

In Europe, most varved sediment profiles have been discovered in glacially overprinted northern and central regions (Fig. 1). Varved sediments were found by chance or after systematic surveys, guided by data from basin and catchment morphometry and geology (Ojala et al. 2000; Zillén et al. 2003). Some of these areas, for instance Scandinavia, are well explored. Approximately 100 lakes with varved sediments were found in Sweden alone (Petterson 1996) and >50 lakes in Finland (Ojala et al. 2000). There are also lakes with

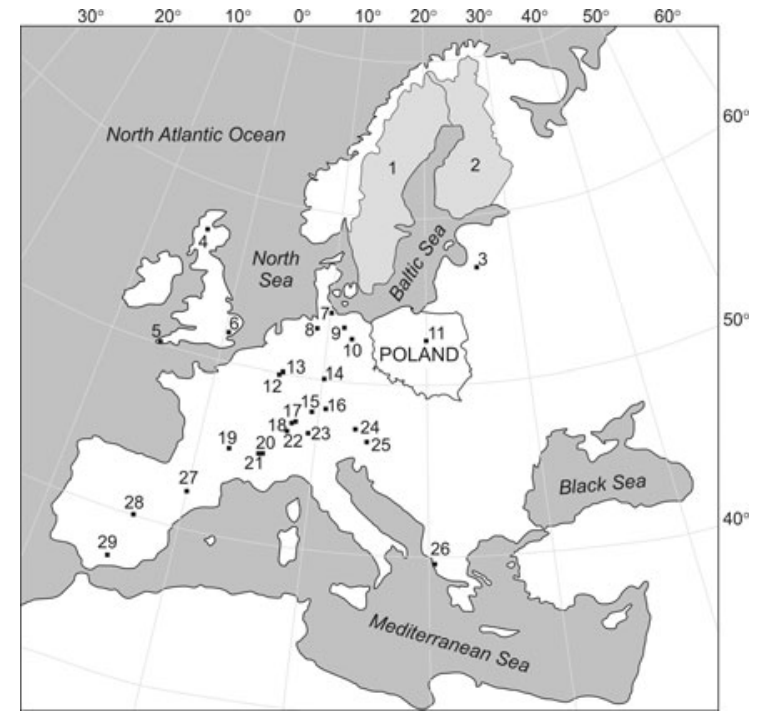

Fig. 1 Distribution of laminated lake sediments in Europe Key: 1 Swedish lakes (Petterson 1996, Zillén et al. 2003); 2 Finish lakes (Ojala et al. 2000); 3 Tougjärv (Veski et al. 2004); 4 Loch Ness (Cooper and O'Sullivan 1998); 5 Loe Pool (Simola et al. 1981); 6 Lake Diss Mere (Peglar et al. 1984); 7 Belauer See (Dörfler et al. 2012); 8 Hämelsee (Merkt and Müller 1999); 9 Woseriner See (Dreibrodt et al. 2002); 10 Sacrower See (Lüder et al. 2006); 11 Lake Gosciąż (Ralska-Jasiewiczowa et al. 1998); 12 Meerfelder Maar (Brauer et al. 1999); 13 Holzmaar (Zolitschka et al. 2000); 14 Frickenhauser See (Enters et al. 2006); 15 Steisslinger See (Eusterhues et al. 2002); 16 Ammersee (Czymzik et al. 2010); 17 Baldeggersee (Lotter et al. 1997); 18 Soppensee (Lotter 1989); 19 Lac Pavin (Stebich et al. 2005); 20 Lac Bramant (Guyard et al. 2007); 21 Lac D'Annecy (Brauer and Casanova 2001); 22 Seebergsee (Hausmann et al. 2002); 23 Silvaplana See (Leemann and Niessen 1994); 24 Mondsee (Wolff et al. 2006); 25 Längsee (Schmidt et al. 2002); 26 Lake Butrint (Ariztegui et al. 2010); 27 Lake Montcortés (Corella et al. 2011); 28 Lake La Cruz (Romero-Viana et al. 2008); 29 Lake Zoñar (Martín-Puertas et al. 2009)

laminated deposits in Germany (Brauer et al. 1999; Zolitschka et al. 2000) and in Alpine regions (Lotter 1989; Leemann and Niessen 1994; Lotter et al. 1997; Brauer and Casanova 2001; Guyard et al. 2007). In contrast, Lake Gościąż in central Poland represents the only site in east-central Europe with a detailed study of a long, annually laminated sediment record (RalskaJasiewiczowa et al. 1998). Despite numerous studies of lake sediment cores from other Polish lakes, only short laminated sections were occasionally found and are related to early stages of lake development (Więckowski 1978). Recently, an intermittently laminated core was reported from Lake Miłkowskie in the Land of Great Masurian Lakes (Wacnik 2009), and 
conditions for deposition of laminated sediments in meromictic Lake Suminko in the Kashubian Lakeland were investigated by Tylmann et al. (2012).

Apparently, northern Poland, with more than 7,000 postglacial lakes of different morphometries and suitable climatic conditions for laminae formation, is a "blank" on the map of varved records in Europe (Fig. 1). This region is, however, important for climate research because data from northeast Poland explain up to $86 \%$ of the variance of winter temperature in eastern Europe and the area shows high teleconnectivity to the dominant North AtlanticEuropean circulation patterns (Luterbacher et al. 2010). Instrumental data for this region cover the last ca. 250 years (Przybylak 2010) and the northern Polish tree-ring series contains a climate record that extends over the past 450 years (Zielski et al. 2010). Data that extend back beyond AD 1550, however, are scarce. Most surprisingly, lake sediment climate archives for this region are lacking, despite their demonstrated potential for climate reconstruction. One reason is the lack of well-documented sites with laminated sediments, which may provide palaeoclimatic and environmental information of appropriate temporal resolution and quality.

Northeastern Poland possesses numerous lakes and has the highest areal density of glacial lakes in Poland (Fig. 2). In the Land of Great Masurian Lakes, the maximum values of the surface area covered by lakes exceed $20 \%$ and values in the range of $5-10 \%$ are common for the entire area. The morphology of this region features a characteristic postglacial landscape, with large changes in elevation, a wide diversity of glacial landforms, and common glaciofluvial deposits. The climate in northeast Poland is characterized by typical continental features indicated by distinct seasonal differences, with an annual amplitude in mean monthly temperatures exceeding $20{ }^{\circ} \mathrm{C}$. The lakes show a wide diversity of morphometric features, hydrological regimes, water chemistries and trophic states, making the area ideal for a survey of potential lacustrine climate archives.

For the above reasons, along with the promising results of initial field work (Tylmann et al. 2006), we undertook a systematic reconnaissance survey of lake sediments in selected parts of northeast Poland with the aim of identifying new sites with laminated sediment sequences that offer the opportunity to conduct research that will shed light on past climate change. With this study, we fill the gap between the better-investigated regions of western and alpine Europe and Scandinavia. The present study also contributes to our ability to recognize the general conditions responsible for biogenic laminae formation and preservation in temperate lakes. We, however, took a further step in this study in that we: (1) took advantage of a unique dataset on the morphology of Polish lakes (2) carefully selected lakes with the highest probability to contain laminated sediments, and (3) statistically analyzed our results with respect to lake and catchment morphology. Our goal was to thoroughly investigate the complex relationships among numerous factors that ultimately lead to the formation and preservation of laminae in lake sediments.

\section{Materials and methods}

\section{Lake selection strategy}

Our strategy for a systematic survey to find laminated lake sediment records followed the approach carried out in Canada (Larsen and MacDonald 1993; Larsen et al. 1998), Finland (Ojala et al. 2000) and Sweden (Zillén et al. 2003). In general, climate conditions suitable for deposition of seasonally different sediment layers, i.e. strong climatic seasonality, prevail throughout northern Poland. Optimal conditions for laminae preservation, however, are expected only in small, deep lake basins, as this morphometry favours anoxic conditions in the hypolimnion because of long stagnation periods and short or incomplete mixing. Therefore, small surface area and large maximum depth (i.e. high relative depth) were assumed to be fundamental preconditions for formation and preservation of laminated sediments in northeast Poland.

To test the above assumptions we conducted investigations in two areas, the Land of Great Masurian Lakes (GML) and the Suwałki Lakeland (SL) (Fig. 2), which are characterized by the highest number of lakes in the region. Within these test areas, detailed analyses of bathymetric maps were performed for lakes larger than $0.1 \mathrm{~km}^{2}$. A morphometric database of 337 lakes was created. This was possible because of the availability of complete morphometric information on lakes in northeast Poland, including bathymetric maps (Jańczak 1999). 


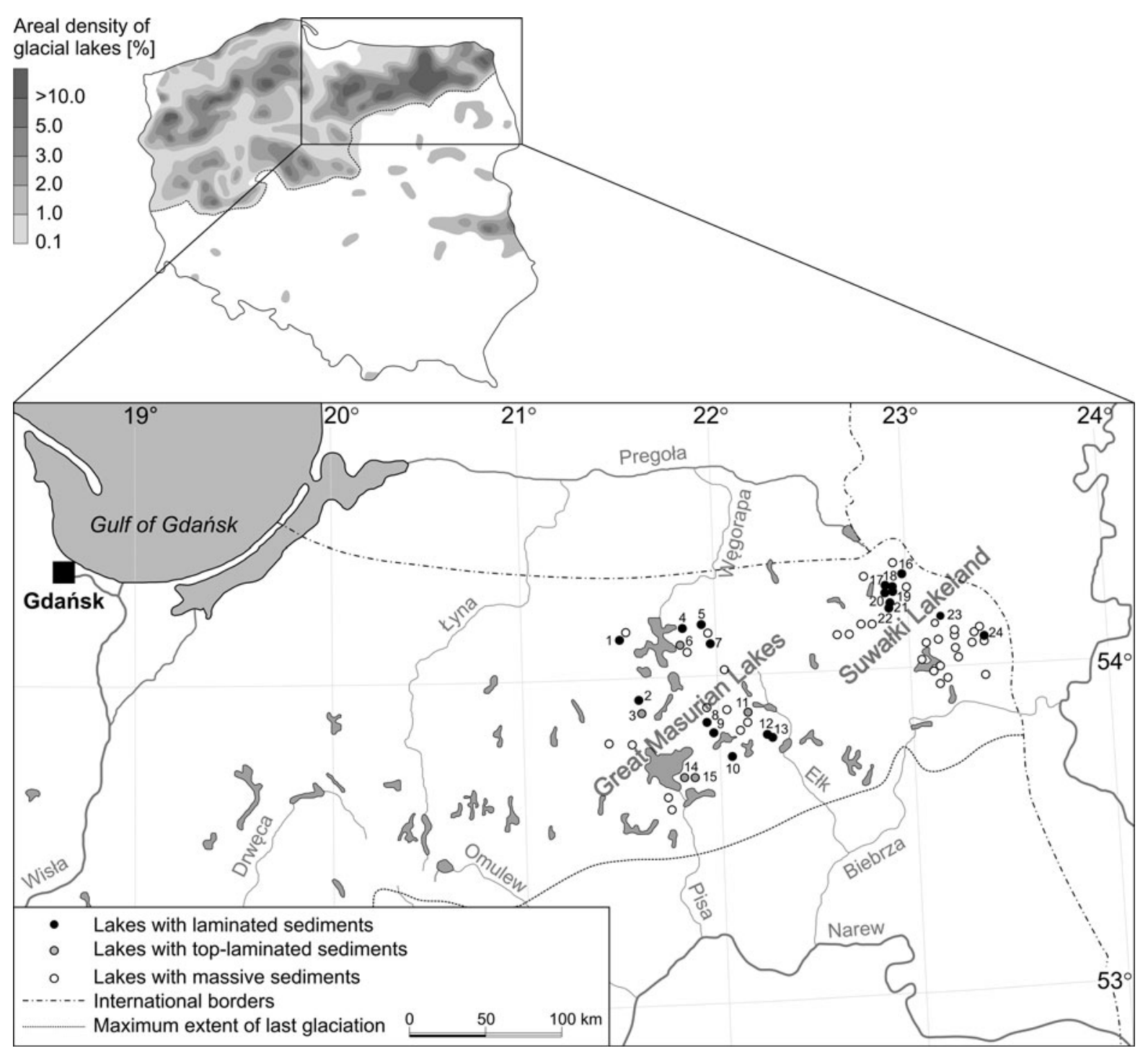

Fig. 2 Areal density of glacial lakes in Poland (Choiński 2008) with location of test areas and lakes cored for this study

Selection of lakes was based on two fundamental morphometric criteria often used as indicators of the potential for preservation of laminated sediments, maximum lake depth and length. Based on a field survey of 297 lakes in the U.S. and Canada, Larsen et al. (1998) estimated the minimum depth required to preserve laminations in sediment records. For lakes with surface areas $\sim 0.1 \mathrm{~km}^{2}$, which is the minimum in our study, the shallowest maximum depth $\left(\mathrm{z}_{\max }\right)$ is in the range 12-18 m. Saarnisto (1986) concluded that annually laminated sediments were mostly found in lakes with a maximum depth $>15 \mathrm{~m}$. Laminae were detected in shallower lakes $\left(\mathrm{z}_{\max }=8.7 \mathrm{~m}\right)$ by Zillén et al. (2003) in a survey conducted in the Swedish province of Värmland. Ojala et al. (2000) found that of 195 lakes surveyed in Finland, the minimum depth sufficient for preservation of varved sediments was 5-6 m, but most lakes with laminated deposits had a maximum depth $>10 \mathrm{~m}$. Statistical analyses of the morphometric data set for the Polish lakes in the test areas showed that even using the most rigorous morphometric criteria the number of selected lakes is still sufficient. Therefore, we used $15 \mathrm{~m}$ as the minimum water depth for lakes to be selected for 
fieldwork. A maximum length criterion was introduced to exclude large lakes, which can also contain laminated sediments in their deep basins, but are much more complex systems because of diverse bottom morphology, water dynamics and catchment conditions. Thus, large lakes are difficult to compare with small lakes in terms of preconditions for laminae formation. All lakes with a maximum length of less than $1.5 \mathrm{~km}$ were selected initially. After analysis of the bathymetric maps, however, 21 lakes with a slightly greater length, but characterized by the presence of isolated deep basins, were added. Using the $\mathrm{z}_{\max }$ and maximum length criteria maximizes the chance that the selected lake, or at least the deepest basin of the lake, is stratified during most of the year, and that appropriate conditions for laminae preservation prevail. In total, 60 lakes from the two study areas were selected for fieldwork.

\section{Fieldwork}

The field strategy involved collecting short $(<1 \mathrm{~m})$ cores from the deepest basins of selected lakes. Sediment cores were taken using a gravity corer equipped with a percussion system to improve penetration (Tylmann 2007). We used 100-cm-long Plexiglas core tubes with an inner diameter of $56 \mathrm{~mm}$, which were cut in half lengthwise prior to fieldwork and re-joined using waterproof tape. Coring was done from a rubber boat positioned with a GPS system. Water depth at the coring sites was checked with an echo sounder. Immediately after retrieval, cores were transported to the lakeshore, where they were opened by removing the waterproof tape, and split lengthwise. Exposed sediment surfaces enabled identification of sediment structures. All cores containing laminated sediments were transported to the laboratory at the University of Gdansk for further analyses.

\section{Laboratory work}

Under laboratory conditions, lamination characteristics were evaluated on cleaned core surfaces, i.e. clarity of boundaries and approximate thickness of individual laminae. After initial description and photographic documentation, the cores were stored under cold-room conditions. Next, the number of distinct black and white couplets in each core was estimated by manual counting from high-resolution digital photos of fresh cores. The most promising cores were scanned with an ITRAX XRF Core-Scanner (Cox Analytical Systems, Croudace et al. 2006) at the GEOPOLAR laboratory (University of Bremen) applying a spatial resolution of $200 \mu \mathrm{m}$ to determine changes in chemical composition of major and minor elements. Sediment slabs from representative parts of the cores with very well preserved laminated sections were impregnated with epoxy resin after shock-freezing and freeze-drying, following the method described by Lotter and Lemcke (1999). Then large-size thin sections were prepared from impregnated sediment blocks. Microstratigraphic analysis of thin sections with a petrographic microscope enabled us to recognize the composition of individual laminae, and for several lakes, the basic varve structure represented by the seasonal pattern of lacustrine deposition.

\section{Statistical data processing}

The database for statistical analysis contains the following morphological characteristics of the lake basins: surface area, length, width, maximum and mean depth, shoreline development index and exposure index (ratio between lake surface area and mean depth). To complement morphological variables, we calculated maximum and mean wind fetch for the coring location of each lake. These values were established by measuring the distance from the coring site to lakeshore using a windrose-type plot with 16 compass direction axes. Mean wind fetch was calculated by averaging 16 individual values obtained for each lake, and maximum fetch is the longest distance from the coring location to lakeshore. Topographic exposure of each lake was calculated in a similar way, by measuring maximum denivelation along $16 \mathrm{com}$ pass directions within a distance of $0.5 \mathrm{~km}$ from the lakeshore and averaging the results. Additional information, which may help interpretation, included the use of satellite images to identify inflows and determine the percentage of shoreline covered by forest. Catchment surface geology was also considered, using 1:50,000-scale geological maps published by the Polish Geological Institute. Also, lake water characteristics (conductivity, $\mathrm{pH}$ and calcium content) were included, using data from the Atlas of Polish Lakes 
(Jańczak 1999). It must be mentioned, however, that these archival data may not be fully comparable between lakes because they are usually based only on measurements carried out once or twice during the last $\sim 30$ years. Because of the sparse nature of the lake water data, we used them mainly as descriptive information to test our interpretation, but they were not included in the dataset for multivariate analysis, where we focused on morphological variables.

Three statistical approaches were used to examine the conditions favourable for laminae accumulation and preservation:

1. Selected variables were analyzed by comparing the mean, standard deviation and extreme values for the three groups of lakes, i.e. those containing laminated, top-laminated, and massive (non-laminated) sediments. To test for statistically significant differences between these groups, we applied a one-way ANOVA and also compared results with the Kruskal-Wallis non-parametric test.

2. We tested the simple model based on lake surface area and depth by applying the equations developed by Larsen and MacDonald (1993) and modified by Larsen et al. (1998) to our lake data set. We also investigated relationships between topographic exposure and different morphological characteristics of the lakes.

3. To characterize the relationships among the variables and laminae occurrence, we used multivariate statistics. The environmental data matrix consists of 60 lakes, each characterized by eight morphological properties: surface area, maximum water depth, mean water depth, exposure index, shoreline development, maximum wind fetch, mean wind fetch and topographic exposure. The environmental data structure was checked by detrended correspondence analysis and the obtained lengths of gradient $(<3 \mathrm{SD})$ allowed for use of linear methods. To detect differences between lakes containing laminated, top-laminated and massive sediments, we applied linear discriminant analysis according to the procedure described by Lepš and Šmilauer (2003) and used CANOCO 4.5 for Windows. The response data matrix was created with three variables related to sediment structure: laminated, top-laminated and massive. Each variable represents a single class and the lakes belonging to a class have a value of 1.0 for this variable and zero values for other variables.

\section{Results}

Distribution of lakes with laminated sediments

Fieldwork covered all 60 lakes selected using morphometric criteria. They are spread equally across the two test areas (Fig. 2) and represent a wide variety of morphological and limnological properties.

Collected cores were up to $95 \mathrm{~cm}$ long and in each case an undisturbed sediment-water interface was recovered. The cores were classified as laminated along the entire length of the core, laminated in the topmost part only, or homogenous (massive). Partial lamination covering the topmost $20-30 \mathrm{~cm}$ was found in several cases. This change in sediment structure was most commonly associated with the transition from pale, highly carbonaceous massive gyttja, to dark, more organic and finely laminated sediment. Homogenous sections (10-20 cm thick) were also present and interrupt some of the laminated sections as well as event layers (turbidites), indicating slumps on the slopes of the lake basin.

Laminated sediments were found in 24 lakes (Fig. 2; Table 1). The highest hit rate (55.6\%) of this method used to search for laminated sediment records was achieved in the GML area, where 15 of 27 tested lakes contained laminated sediments. In the case of the SL, it was only 9 of 33 checked lakes (27.3\%). Spatial distribution of lakes with laminated sediments shows no general trend in the GML, but there is characteristic occurrence of paired lakes located in the immediate vicinity. This situation occurs often when two lakes of similar morphometry are located in the same landform, e.g. along a long glacial channel (Lakes Łazduny and Rzęśniki) or an elongated melt-out depression (Lakes Rogale Duże and Rogale Małe). In contrast, one distinguishable cluster was found in the SL, where seven lakes are located in the northern part within a distance of $<15 \mathrm{~km}$. This area is characterized by complex topography, excellent preservation of glacial geomorphology, and an abundance of small lakes of sufficient depth to fulfill our morphometric criteria. These lakes are well protected 


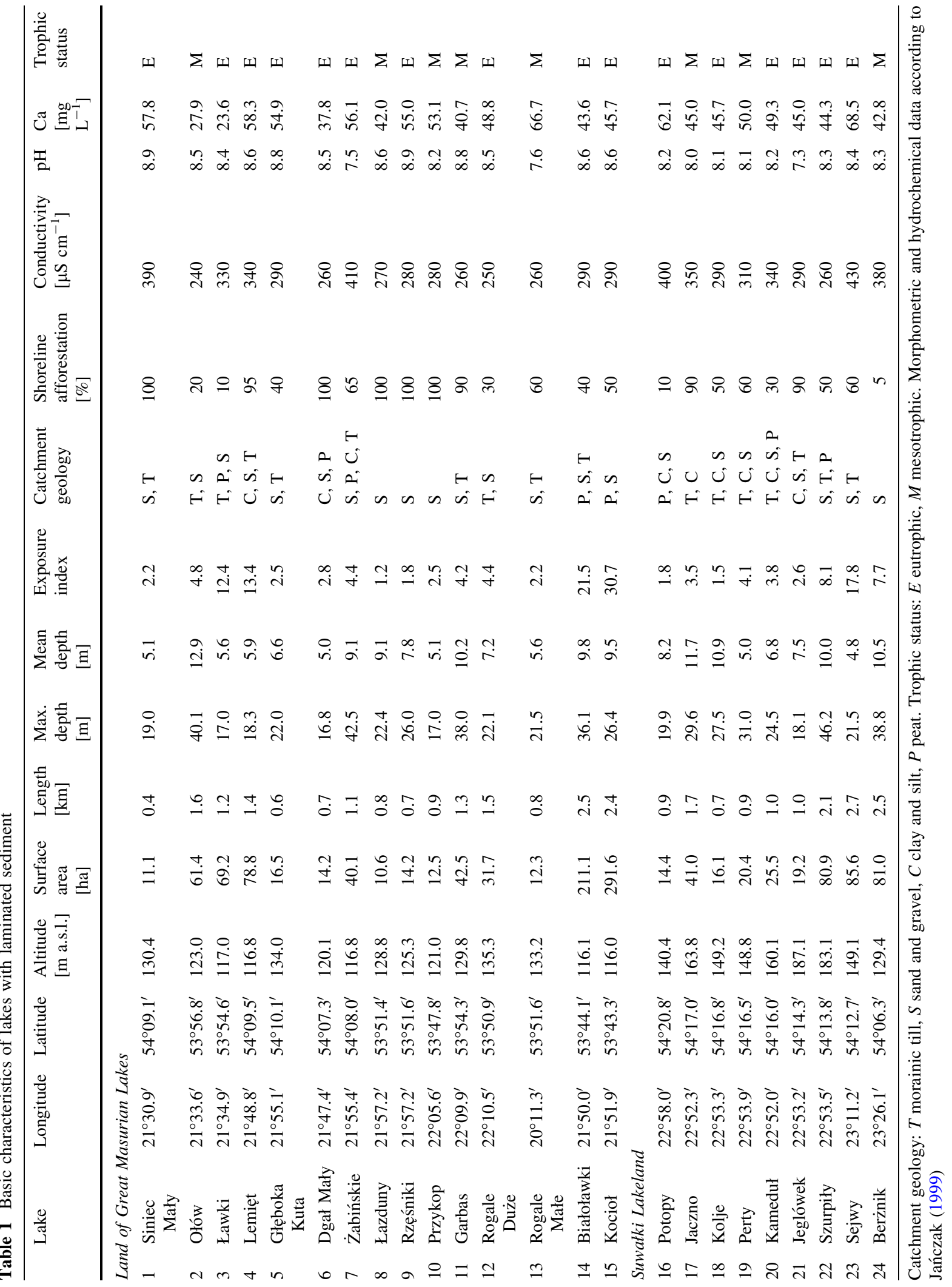


Table 2 Basic statistics (mean, standard deviation, range) for lakes with laminated, top-laminated and massive sediment cored for this study

\begin{tabular}{|c|c|c|c|c|c|c|}
\hline \multirow[t]{2}{*}{ Parameter } & \multicolumn{2}{|c|}{ Laminated $(n=17)$} & \multicolumn{2}{|c|}{ Top-laminated $(n=7)$} & \multicolumn{2}{|c|}{ Massive $(n=36)$} \\
\hline & Range & Mean \pm SD & Range & Mean \pm SD & Range & Mean \pm SD \\
\hline Surface area $\left[\mathrm{km}^{2}\right]$ & $0.11-0.81$ & $0.30 \pm 0.24$ & $0.14-2.92$ & $1.13 \pm 1.00$ & $0.10-2.28$ & $0.59 \pm 0.46$ \\
\hline Max. depth [m] & $17.0-46.2$ & $27.5 \pm 9.15$ & $16.8-38.0$ & $24.9 \pm 8.97$ & $15.1-49.6$ & $26.1 \pm 9.50$ \\
\hline Mean depth [m] & $5.00-12.9$ & $8.18 \pm 2.43$ & $4.80-10.2$ & $7.26 \pm 2.45$ & $3.50-17.4$ & $7.70 \pm 2.70$ \\
\hline Length $[\mathrm{km}]$ & $0.40-2.46$ & $1.11 \pm 0.55$ & $0.65-2.67$ & $1.74 \pm 0.78$ & $0.48-3.90$ & $1.48 \pm 0.79$ \\
\hline Width [km] & $0.21-0.78$ & $0.41 \pm 0.16$ & $0.29-1.70$ & $0.87 \pm 0.56$ & $0.21-1.33$ & $0.59 \pm 0.29$ \\
\hline Shoreline development & $1.02-2.19$ & $1.55 \pm 0.34$ & $1.09-2.28$ & $1.40 \pm 0.42$ & $1.10-3.10$ & $1.60 \pm 0.40$ \\
\hline Max. fetch $[\mathrm{km}]$ & $0.21-1.10$ & $0.51 \pm 0.24$ & $0.39-1.50$ & $0.91 \pm 0.40$ & $0.28-2.15$ & $0.77 \pm 0.42$ \\
\hline Mean fetch $[\mathrm{km}]$ & $0.16-0.38$ & $0.24 \pm 0.07$ & $0.22-0.94$ & $0.51 \pm 0.28$ & $0.17-0.78$ & $0.33 \pm 0.12$ \\
\hline Exposure index & $1.20-8.10$ & $3.48 \pm 2.00$ & $2.80-30.7$ & $14.7 \pm 9.75$ & $1.00-21.9$ & $8.20 \pm 5.90$ \\
\hline Topographic exposure [m] & $6.06-43.3$ & $19.0 \pm 7.77$ & $5.20-29.7$ & $10.9 \pm 8.86$ & $3.70-20.9$ & $11.8 \pm 4.20$ \\
\hline Shoreline afforestation [\%] & $0-100$ & $45.9 \pm 37.6$ & $5-100$ & $48.6 \pm 33.5$ & $0-100$ & $31.3 \pm 37.1$ \\
\hline Conductivity $\left[\mu \mathrm{S} \mathrm{cm}^{-1}\right]$ & $230-510$ & $328 \pm 79$ & $260-430$ & $315 \pm 60$ & $40-520$ & $280 \pm 94$ \\
\hline $\mathrm{pH}$ & $7.3-8.9$ & $8.3 \pm 0.4$ & $8.4-8.8$ & $8.6 \pm 0.1$ & $7.6-9.1$ & $8.4 \pm 0.3$ \\
\hline $\mathrm{Ca}\left[\mathrm{mg} \mathrm{L}^{-1}\right]$ & $27.9-66.7$ & $49.8 \pm 9.0$ & $23.6-68.5$ & $45.5 \pm 14.5$ & $6.4-89.3$ & $42.9 \pm 15.1$ \\
\hline
\end{tabular}

Parameters that show statistically significant $(P<0.05)$ differences between the groups of lakes are marked in italics

from wind by virtue of their sheltered location in depressions among moraine ridges.

\section{Conditions for preservation of laminated} sediments

Analysis of basic statistical parameters, such as means, standard deviations and extremes, for the three investigated groups of lakes with laminated, toplaminated and massive sediments, shows statistically significant differences only for some morphological variables (Table 2) related to size and shape of lakes (surface, width, maximum and mean fetch) and catchment morphology (topographic exposure). Maximum depth is not a variable that differentiates these groups of lakes from one another. Mean depth, however, is important because it determines the exposure index, which differs strongly between the lake groups.

We applied equations based on simple morphometric variables to check how surface area and maximum depth influence the occurrence of laminated sediments in lakes of northeast Poland (Fig. 3). Because we selected lakes according to rigorous criteria related to size and depth, none of the lakes were shallower than the value calculated from the equation $\mathrm{Z}_{\max }=3.0 \mathrm{~A}_{0}^{0.294}$. Looking at the position of

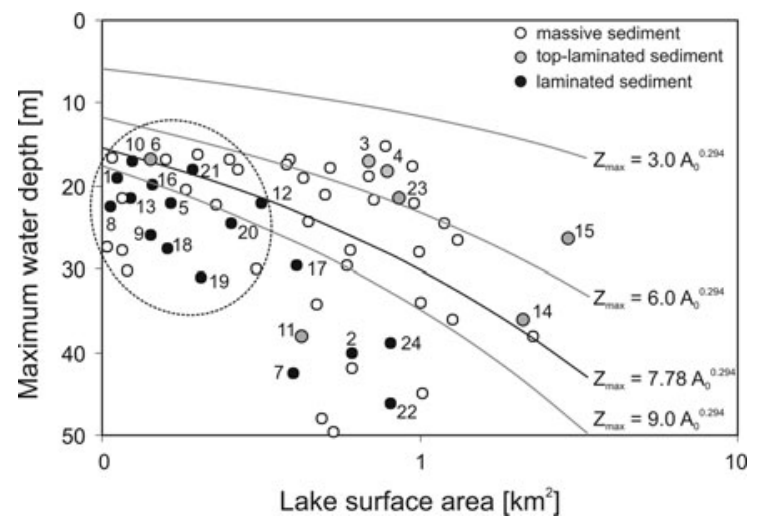

Fig. 3 Relation between lake surface area, maximum water depth and the occurrence of laminated, top-laminated and massive sediment for 60 lakes surveyed in northeastern Poland. A cluster of 25 lakes with similar morphometric features is circled

lakes in relation to other equation lines, it is evident that most of the lakes containing laminated sediments (19 lakes, 79.2\%) have a maximum depth equal to or greater than the value calculated according to the equation $Z_{\max }=7.78 \mathrm{~A}_{0}^{0.294}$, which was found by Larsen and MacDonald (1993) to be the minimum value for lakes to develop laminated sediments. Only five lakes are shallower than this value and in all of them, we found topmost laminations only. Lakes with massive sediments, however, are equally distributed 
below and above this equation line. One cluster, including 25 lakes with similar area/maximum depth ratios can be distinguished (Fig. 3). These lakes are characterized by surface areas $\leq 0.3 \mathrm{~km}^{2}$ and maximum depths in the range 15-35 $\mathrm{m}$. Among this group, 13 lakes contain laminated sediments. Therefore, the hit rate of our field survey in this case was better than $50 \%$. For larger lakes, we found only 11 with laminated sediments (hit rate of $31 \%$ ).

To check the importance of catchment morphology for the deposition of laminated sediments, we tested relationships between topographic exposure and various morphometric characteristics of respective lake basins (Fig. 4). Plots of topographic exposure versus mean and maximum depth show no direct relationship and lakes with laminated and top-laminated sediments are scattered among lakes with massive deposits. The relationship between topographic exposure and wind fetch, however, allows for discrimination of lakes containing laminated sediments. Best results were obtained using more complex variables that describe lake basin morphology, i.e. the ratio between mean fetch and maximum depth, and exposure index. These variables, taking into account both size and depth of a lake, plotted against topographic exposure, provide a substantially clearer picture of morphological conditions favourable for the deposition of laminated sediments. Low values of the mean fetch/maximum depth ratio $(<10)$ in connection with high values of topographic exposure $(>10)$ give the highest hit rate of $70 \%$ (14 of 20 lakes). The same settings for exposure index and topographic exposure give a hit rate of $51.5 \%$ (17 of 33 lakes). The use of these morphological variables clearly indicates the difference between lakes that contain laminated and top-laminated sediments. In our case, topmost lamination was found mostly in lakes characterized by a lower degree of sheltering (values of topographic exposure $<10$ ) and
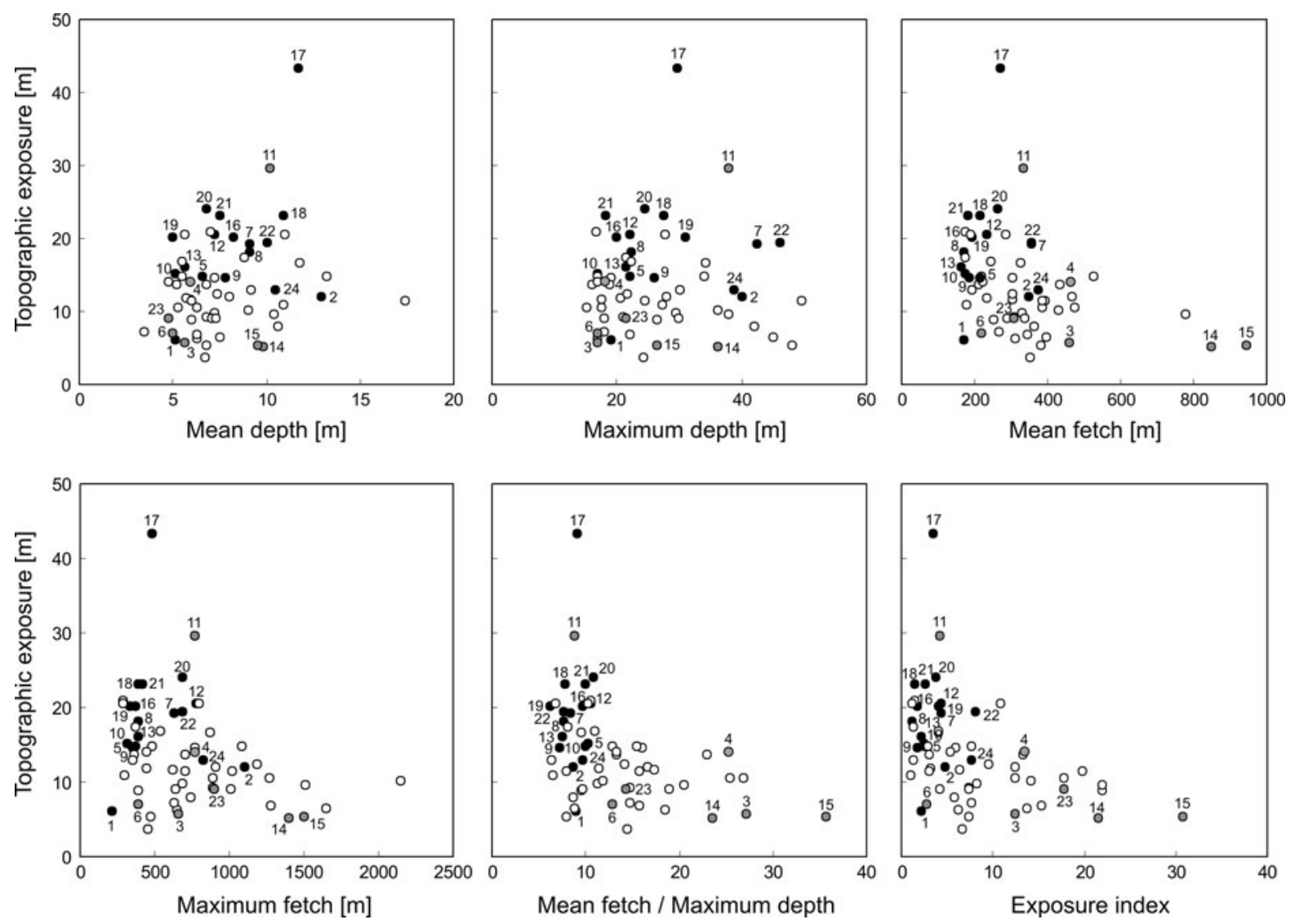

Fig. 4 Relations between topographic exposure of lakes, selected morphological variables of lake basins and the occurrence of laminated, top-laminated and massive sediment for 60 lakes surveyed in northeastern Poland. Legend is the same as in Fig. 3 
generally by higher values of other variables in the data set.

The lake data set was subjected to a multivariate LDA, which analysed linear combinations of these environmental variables that optimally separate the three pre-specified sediment classes (laminated, toplaminated, massive). Despite a complex structure of relationships between analyzed elements and lakes, the LDA biplot reveals a cluster of lakes containing laminated sediments (Fig. 5). These lakes are characterized by positive loadings of topographic exposure, maximum and mean depth, and negative loadings of area, exposure index, maximum and mean fetch. The strong relation between lakes with laminated sediments and topographic exposure highlights the fact that only the combination of catchment morphology and appropriate lake basin variables effectively promotes the deposition of laminated sediments. In contrast, lakes with top-laminated sediments are widely scattered within the two-dimensional discriminant-axes space, but are generally characterized by positive loadings of area, exposure index, maximum and mean fetch, and negative loading of topographic exposure. This suggests that factors other than morphology influence recent deposition of laminated sediments in these lakes. Lakes that we found to contain massive sediments are not clearly separated from other classes and occur under various morphological conditions. This indicates that

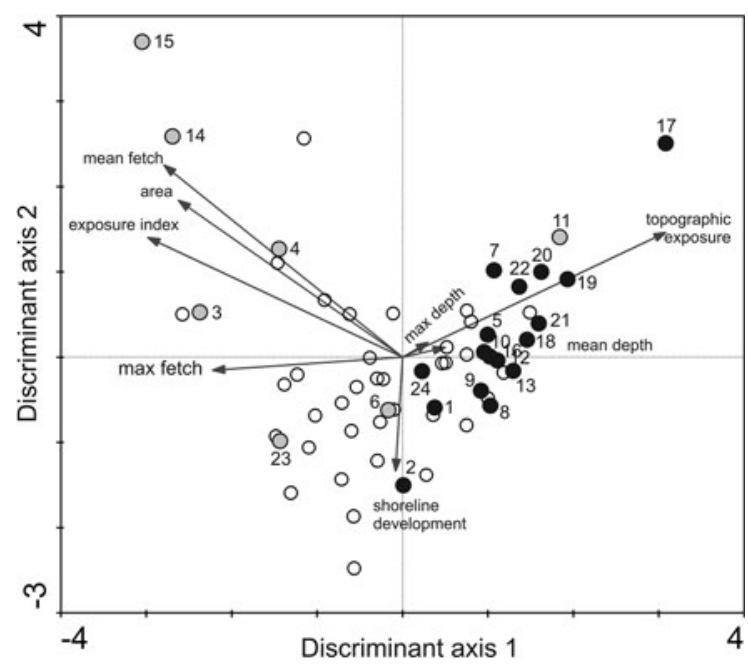

Fig. 5 Results of a LDA representing relationships between analyzed morphological variables and the occurrence of laminated, top-laminated and massive sediment for the studied lakes in northeastern Poland. Legend is the same as in Fig. 3 the combination of morphological variables alone does not completely explain the conditions responsible for the formation of laminated or massive sediments.

\section{Types of laminations}

Microscopic and geochemical analyses indicate a biogenic (calcite) type of lamination as characteristic of lakes in northeast Poland (Table 3). This type is generally characterized by a spring-summer lamina rich in calcium carbonate and a dark autumn-winter lamina, consisting mostly of organic and minerogenic detritus. An example of this kind is found in the sediment record from Lake Łazduny, which shows a regular succession of autochthonous calcite layers and organic-rich layers containing diatom frustules, chrysophyte cysts, organic fragments and amorphous organic matter (Fig. 6). Despite differences in laminae thickness, we observed a similar sediment composition in most of the lakes from northeast Poland that contain laminated sediments. This simple pattern of sedimentation, however, can be more complex, e.g. several calcite layers can occur as a result of multiple algal blooms during one growing season (Fig. 6). The cyclic nature of these structures suggests an annual sedimentation pattern, although this needs to be confirmed by sediment trap studies and independent dating.

An exception to the dominant type of biogenic carbonaceous lamination is found in Lake Jaczno, in which the most prominent component of the laminated sediment is clastic material. Microscopic analyses of thin sections show a complex structure with several types of distinguishable laminae: (1) a thin diatom lamina; (2) a calcite lamina with contributions of amorphous organic matter and diatoms; (3) a second lamina composed exclusively of diatoms (4) a thick lamina composed of detrital matter (quartz, clay minerals, organic fragments) and (5) a lamina composed of amorphous organic matter. A major source of clastic material seems to be surface inflow, which enters the lake close to the coring site. Substantial contributions of minerogenic matter may also be the result, at least partially, of catchment topography. The north basin of Lake Jaczno, where the core was taken, is surrounded by steep slopes, which are in large part deforested and thus prone to gully erosion. Minerogenic matter must have been delivered to the lake by streams that flowed, episodically, through these gullies. Despite this complex structure, clear seasonal 
Table 3 Basic characteristics for laminations of investigated lakes

\begin{tabular}{|c|c|c|}
\hline Lake & Core length $[\mathrm{cm}]$ & Description \\
\hline \multicolumn{3}{|c|}{ Land of Great Masurian Lakes } \\
\hline Siniec Mały & 66 & $\begin{array}{l}\text { Biogenic (calcite) lamination along the entire core, preservation good in uppermost part } \\
\text { and worse downcore, } \approx 110 \text { laminae couplets counted with a mean thickness of } \\
\approx 1.5 \mathrm{~mm}\end{array}$ \\
\hline Ołów & 68 & $\begin{array}{l}\text { Biogenic (calcite) lamination along the entire core, preservation poor, laminae couplets } \\
\text { impossible to count macroscopically }\end{array}$ \\
\hline Ławki & 52 & $\begin{array}{l}\text { Biogenic (calcite) lamination in topmost } 19 \mathrm{~cm} \text { of olive brown sediment, preservation } \\
\text { moderate, } \approx 21 \text { laminae couplets counted with a mean thickness of } \approx 9.0 \mathrm{~mm} \text {, olive } \\
\text { brown massive sediment in lowermost part of the core }\end{array}$ \\
\hline Lemięt & 50 & $\begin{array}{l}\text { Biogenic (calcite) lamination in topmost } 42 \mathrm{~cm} \text { of blackish sediment, preservation good, } 32 \\
\text { laminae couplets counted with a mean thickness of } 13.1 \mathrm{~mm} \text {, olive brown sediment in } \\
\text { lowermost part of the core }\end{array}$ \\
\hline Głęboka Kuta & 95 & $\begin{array}{l}\text { Biogenic (calcite) lamination along the entire core, preservation good, } 99 \text { laminae couplets } \\
\text { counted with a mean thickness of } 9.6 \mathrm{~mm} \text {, massive layers visible in lower part of the core }\end{array}$ \\
\hline Dgał Mały & 56 & $\begin{array}{l}\text { Biogenic (calcite) lamination in topmost } 42 \mathrm{~cm} \text { of blackish sediment, preservation good, } 41 \\
\text { laminae couplets counted with a mean thickness of } 10.2 \mathrm{~mm} \text {, olive brown massive } \\
\text { sediment in lowermost part of the core }\end{array}$ \\
\hline Żabińskie & 95 & $\begin{array}{l}\text { Biogenic (calcite) lamination along the entire core, preservation excellent, } 113 \text { laminae } \\
\text { couplets counted with a mean thickness of } 8.4 \mathrm{~mm}\end{array}$ \\
\hline Łazduny & 90 & $\begin{array}{l}\text { Biogenic (calcite) lamination along the entire core, preservation good, } \approx 500 \text { laminae } \\
\text { couplets counted with a mean thickness of } \approx 1.8 \mathrm{~mm} \text {, massive layers visible along the } \\
\text { core }\end{array}$ \\
\hline Rzęśniki & 84 & $\begin{array}{l}\text { Biogenic (calcite) lamination along the entire core, preservation good in uppermost part } \\
\text { and worse downcore, } \approx 250 \text { laminae couplets counted with a mean thickness of } \\
\approx 3.0 \mathrm{~mm}\end{array}$ \\
\hline Przykop & 72 & $\begin{array}{l}\text { Biogenic (calcite) lamination along the entire core, preservation poor, laminae couplets } \\
\text { impossible to count macroscopically }\end{array}$ \\
\hline Garbas & 79 & $\begin{array}{l}\text { Biogenic (calcite) lamination in topmost } 36 \mathrm{~cm} \text { of blackish sediment, preservation } \\
\text { moderate, } \approx 45 \text { laminae couplets counted with a mean thickness of } \approx 8 \mathrm{~mm} \text {, light grey } \\
\text { massive sediment in lowermost part of the core }\end{array}$ \\
\hline Rogale Duże & 70 & $\begin{array}{l}\text { Biogenic (calcite) lamination along the entire core, preservation moderate, } \approx 30 \text { laminae } \\
\text { couplets counted with a mean thickness of } \approx 9.0 \mathrm{~mm} \text {, in the lowermost part laminae } \\
\text { impossible to count macroscopically }\end{array}$ \\
\hline Rogale Małe & 65 & $\begin{array}{l}\text { Biogenic (calcite) lamination along the entire core, preservation poor, laminae impossible } \\
\text { to count macroscopically }\end{array}$ \\
\hline Białoławki & 67 & $\begin{array}{l}\text { Biogenic (calcite) lamination in topmost } 26 \mathrm{~cm} \text { of blackish sediment, preservation good, } 42 \\
\text { laminae couplets counted with a mean thickness of } 6.2 \mathrm{~mm} \text {, light grey massive sediment } \\
\text { in lowermost part of the core }\end{array}$ \\
\hline Kocioł & 53 & $\begin{array}{l}\text { Biogenic (calcite) lamination in topmost } 18 \mathrm{~cm} \text { of blackish sediment, preservation } \\
\text { moderate, } \approx 25 \text { laminae couplets counted with a mean thickness of } \approx 7 \mathrm{~mm} \text {, blackish } \\
\text { sediment in lowermost part of the core }\end{array}$ \\
\hline \multicolumn{3}{|c|}{ Suwatki Lakeland } \\
\hline Potopy & 72 & $\begin{array}{l}\text { Biogenic (calcite) lamination along the entire core, preservation good, } \approx 80 \text { laminae } \\
\text { couplets counted with a mean thickness of } \approx 7.4 \mathrm{~mm}, \text { in the lowermost part laminae } \\
\text { impossible to count macroscopically }\end{array}$ \\
\hline Jaczno & 82 & $\begin{array}{l}\text { Biogenic (calcite) lamination in topmost } 18 \mathrm{~cm} \text {, preservation good, } \approx 50 \text { laminae couplets } \\
\text { counted with a mean thickness of } \approx 3.6 \mathrm{~mm} \text {, more complex lamination structure with } \\
\text { substantial clastic input downcore, laminae impossible to count macroscopically }\end{array}$ \\
\hline Kolje & 78 & $\begin{array}{l}\text { Biogenic (calcite) lamination in topmost } 20 \mathrm{~cm} \text {, preservation good, } \approx 45 \text { laminae couplets } \\
\text { counted with a mean thickness of } \approx 4.6 \mathrm{~mm} \text {, more complex lamination structure with } \\
\text { clastic input downcore, laminae impossible to count macroscopically }\end{array}$ \\
\hline
\end{tabular}


Table 3 continued

\begin{tabular}{|c|c|c|}
\hline Lake & Core length $[\mathrm{cm}]$ & Description \\
\hline Perty & 67 & $\begin{array}{l}\text { Biogenic (calcite) lamination along the entire core, preservation good but sediment very } \\
\text { porous, } \approx 100 \text { laminae couplets counted with a mean thickness of } \approx 5.6 \mathrm{~mm} \text {, in the } \\
\text { lowermost part laminae impossible to count macroscopically }\end{array}$ \\
\hline Kameduł & 92 & $\begin{array}{l}\text { Biogenic (calcite) lamination in topmost } 36 \mathrm{~cm} \text {, preservation good, } \approx 45 \text { laminae couplets } \\
\text { counted with a mean thickness of } \approx 8.0 \mathrm{~mm} \text {, more complex lamination structure with } \\
\text { clastic input downcore, laminae impossible to count macroscopically }\end{array}$ \\
\hline Jeglówek & 66 & $\begin{array}{l}\text { Biogenic (calcite) lamination along the entire core, preservation poor, laminae impossible } \\
\text { to count macroscopically }\end{array}$ \\
\hline Szurpiły & 73 & $\begin{array}{l}\text { Biogenic (calcite) along the entire core, preservation moderate, } \approx 170 \text { laminae couplets } \\
\text { counted with a mean thickness of } \approx 3.0 \mathrm{~mm} \text {, massive layer between } 5-27 \mathrm{~cm} \text { sediment } \\
\text { depth }\end{array}$ \\
\hline Sejwy & 49 & $\begin{array}{l}\text { Biogenic (calcite) lamination in topmost } 20 \mathrm{~cm} \text { of blackish sediment, preservation } \\
\text { moderate, } \approx 70 \text { laminae couplets counted with a mean thickness of } \approx 7.4 \mathrm{~mm} \text {, light grey } \\
\text { massive sediment in lowermost part of the core }\end{array}$ \\
\hline Berżnik & 58 & $\begin{array}{l}\text { Biogenic (calcite) lamination along the entire core, preservation poor, laminae impossible } \\
\text { to count macroscopically }\end{array}$ \\
\hline
\end{tabular}

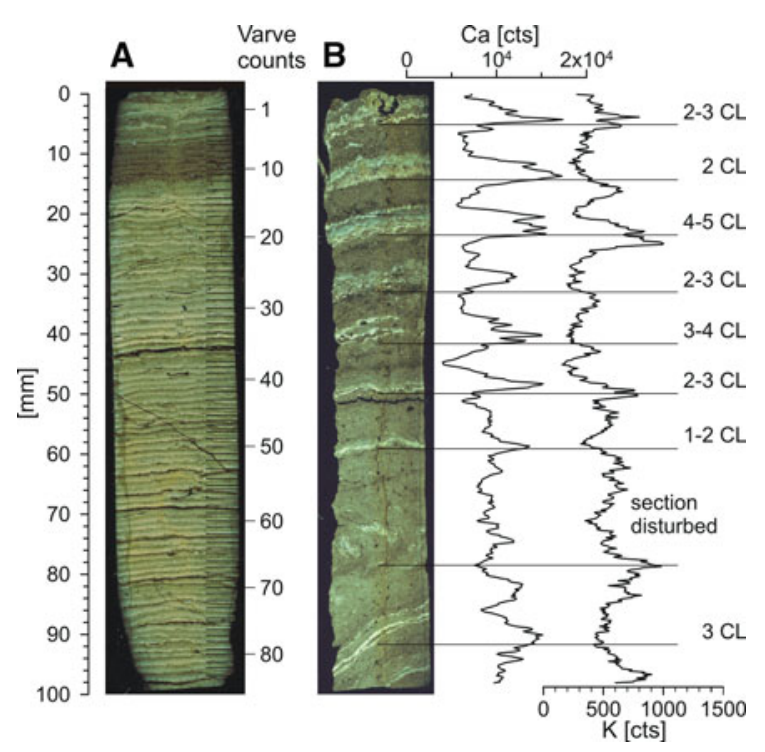

Fig. 6 Examples of biogenic (calcite) laminations. a Flat-bed scan of a thin section showing fine and regular lamination in the sediment from Lake Łazduny. One varve consists of a white spring-summer lamina and dark fall-winter lamina. b Flat-bed scan of a thin section showing multiple calcite layers from Lake Potopy compared to calcium (Ca) and potassium (K) XRF scanning data. Horizontal lines mark varve boundaries. Up to five pale calcite layers (CL) can be distinguished for one annual cycle and they are marked by peaks in $\mathrm{Ca}$. Fall-winter laminae are commonly related to $\mathrm{K}$ maxima indicating the flux of minerogenic matter to the lake

patterns of major element distribution mark the annual cycle and should enable to develop a reliable varve chronology (Fig. 7). Recognizable inputs of clastic material were also found in some core sections from Lakes Kolje, Kamenduł and Potopy located in the same area.

Mean thicknesses of laminae couplets in the uppermost sediment vary between lakes from 1.5 to $>10 \mathrm{~mm}$, with the most common values in the range of 3-8 mm. In several lakes, however, we found unusual thicknesses, up to several centimetres. In Lake Głęboka Kuta, located in the GML, macroscopic analysis indicates core sections with regular laminae couplets $2-3 \mathrm{~cm}$ thick. Such high sedimentation rates can occur because of sediment focusing that occurs in lakes with small, deep basins surrounded by steep slopes. Such morphological factors also cause turbidite sedimentation, which usually results in deposition of massive layers and sediment erosion, which makes it difficult to achieve a reliable varve chronology.

\section{Discussion}

Northeast Poland is rich in lakes containing laminated sediments. It has not been confirmed, however, whether such laminations are annual in every case because their structure has only been examined in detail in several sediment records. Links between structure and composition of laminations and seasonal variability of limnological processes, however, suggest that laminations are annual and that couplets or more complicated seasonally deposited structures can be regarded as varves. This 
Fig. 7 Flat-bed scan of a thin section showing seasonal changes in annually laminated sediment from Lake Jaczno compared to XRF scanning data

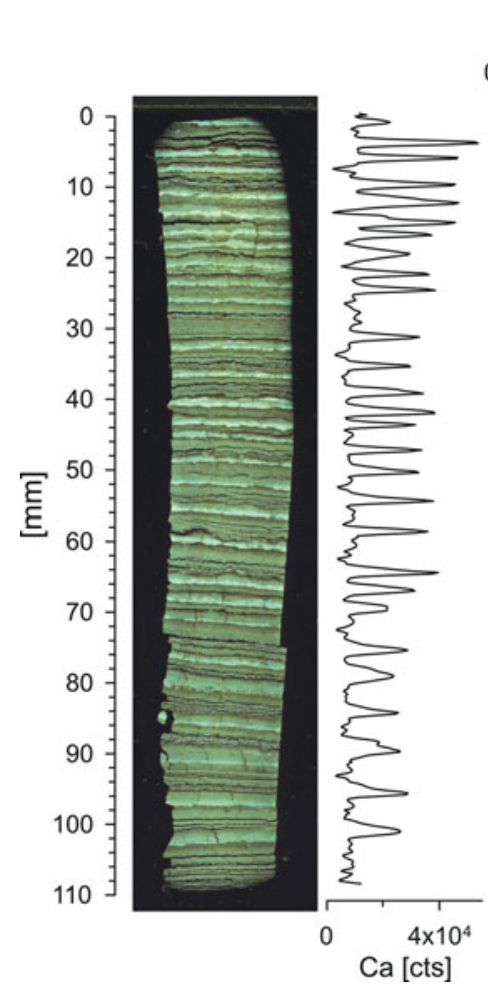

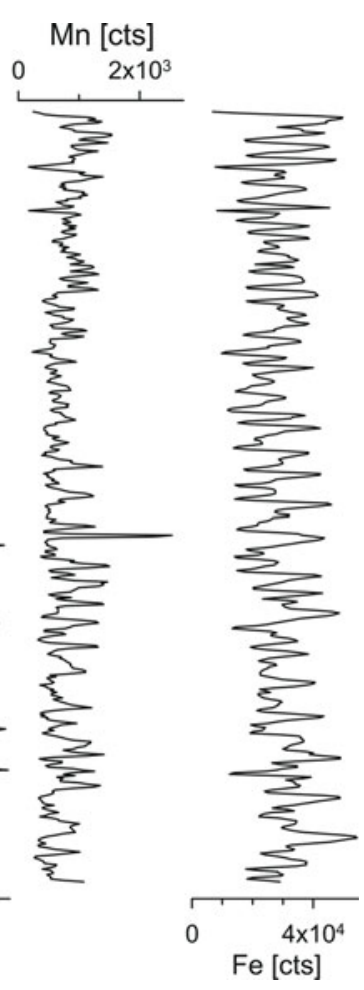

was confirmed by independent dating $\left({ }^{14} \mathrm{C},{ }^{210} \mathrm{~Pb}\right.$ and ${ }^{137} \mathrm{Cs}$ ) of selected sediment records, which show excellent agreement with varve counting (Kinder et al. 2013; Tylmann et al. 2013). Our study lakes indicate that the biogenic (calcite) type of lamination is typical for lakes in northeast Poland. Although in this study we examined only the uppermost sediments that cover the last several hundred years at most, ongoing investigations show there is potential to obtain long varved records. For instance, at Lake Szurpiły we found continuous annual laminations covering the last $8,410 \pm 101$ years (Kinder et al. 2013). Other lakes with laminated sediment records that are currently under study (Lakes Łazduny and Żabińskie) cover the entire Holocene, i.e. 11,650 cal years BP.

In our analysis of conditions favorable for the formation and preservation of biogenic laminae in lake sediments, no straightforward relationship between limnologic variables and presence of laminae emerged. One reason may be the fact that we used rigid criteria at the outset to select lakes with the highest theoretical potential to contain laminated sediments. As a consequence of this rigorous selection process, the range of variables was limited in our dataset. Thus, discrimination of factors that are responsible for laminae formation was not simple. We were looking for significant differences in a population of similar lakes, and to do so, we used a range of variables and multivariate statistics to identify the most important factors leading to laminae formation.

The factors most important in laminae formation are related to lake and catchment morphology. Lakes that are deep relative to their surface area are more likely to contain laminated sediments than are shallow lakes (O’Sullivan 1983; Saarnisto 1986; Larsen et al. 1998). The lakes most likely to possess laminated deposits have a surface area of $<0.3 \mathrm{~km}^{2}$ and a maximum depth in the range $15-35 \mathrm{~m}$. The ideal lake for laminae formation is deeply incised into the catchment and surrounded by forest. This particular combination of lake basin morphology, topographic position and land use results in minimal influence of external factors (wind action) and dominance of short water-column circulation periods, incomplete mixis or even permanent stratification, i.e. meromixis (Tylmann et al. 2012).

On the other hand, Ojala et al. (2000) showed that the formation of laminated lake sediments can be controlled not only by lake morphometry, but also by 
several other interacting environmental factors, such as catchment geology and surface inflows. Occurrence of fine-grained clastic sediment in the catchment is especially important for the formation of the clasticorganic type of lamination, which is widely known from Scandinavia (Renberg 1981; Zillén et al. 2003; Ojala and Alenius 2005) and typically contains characteristic minerogenic laminae formed during spring floods. In lakes of northeast Poland, however, seasonal input of minerogenic matter is of minor importance and catchment conditions seem to play a secondary role. Only in three of the investigated lakes we did observe substantial seasonal clastic input, recorded as individual lamina.

Unlike the conditions for formation of clasticorganic laminations, morphological factors and conditions suitable for laminae preservation at the lake bottom seem to be essential for the formation of biogenic laminations, which are composed mainly of autochthonous matter. Models based on morphometric properties of lake basins (Larsen and MacDonald 1993; Larsen et al. 1998) are useful tools for locating lakes containing biogenic laminations. Simple theoretical assumptions do not explicitly determine the occurrence or absence of laminated sediments, but may maximize the probability of identifying lakes with laminated deposits and thus optimize field efforts. More sophisticated statistical analysis (LDA) consistently discriminates a group of lakes with similar morphometric features most prone to contain laminated sediments.

Defining optimal conditions for partial lamination was difficult using our approach. Because this type of lamination is commonly found in the most recent part of the record, it is more likely related to cultural eutrophication and associated changes in the bottomwater oxygen regime (Lüder et al. 2006), rather than to any morphological variable. Most of the lakes with topmost lamination were in the GML, where development of both agriculture and tourism has caused considerable eutrophication of surface waters during the last 50 years (Marszelewski 2005). Our results show that lakes with only topmost lamination are substantially different from lakes with laminated sediments. They have a larger area, greater wind fetch and may be located in relatively flat areas. However, any morphological variable or combination of variables can be responsible for the occurrence of partially laminated sediments.
The above findings indicate that knowledge of morphological conditions alone cannot give a definitive answer to the question of which conditions are responsible for the occurrence of laminated sediments in northeast Poland. There are other factors related to seasonal processes in individual lakes, e.g. intensity of primary production, duration of periods with anoxic conditions in near-bottom waters, carbonate precipitation controlled by phosphorus concentrations in the lake water, etc. that play a role in laminae formation. Therefore, a better understanding of limnological and hydrochemical processes is necessary to explain why, in a group of lakes with optimal lake basin and catchment morphology for laminae formation, we found both laminated and massive sediments.

The surprisingly large group of lakes with laminated sediments sheds new light on the potential for limnogeological studies in northeast Poland. First, organictype laminations possess a range of biological and geochemical proxies that can be used for environmental reconstruction. Second, sedimentation rates on the order of several mm per year offer the opportunity to conduct high-resolution studies. Using microscopic analysis of thin sections (Hambley and Lamoureux 2006) and nondestructive techniques like XRF core scanning (Zolitschka et al. 2001) or scanning reflectance spectroscopy in the visible spectrum (VIS-RS; 380-730 nm) (Trachsel et al. 2010), annual or even seasonal resolution of changes in sediment composition can be obtained (Figs. 6, 7). Cyclic changes in chemical composition include indicators for the supply of minerogenic matter $(\mathrm{K}, \mathrm{Si})$, calcite deposition $(\mathrm{Ca})$, as well as changing redox conditions $(\mathrm{Fe}, \mathrm{Mn})$. The high-resolution signal of environmental conditions preserved in these lakes allows for precise temporal analysis of rapid climate change, extreme events and human impacts.

Results from our two study areas underline the probability that there are still many undiscovered sites with laminated sediment records in this part of Europe. It is of crucial importance to carry out comparable field surveys in areas that have not been sufficiently explored, such as the postglacial lakelands of Eastern Europe, i.e. in the Baltic States and Russia. Expanding the inventory of laminated sediment records may provide a chance to carry out investigations focused on regional comparisons along transects that represent large variations in environmental conditions, which may shed light on new aspects of environmental variability since the last glaciation. 


\section{Conclusions}

Our field survey confirmed that careful selection of lakes based on their morphometric features is a powerful tool to help identify lakes with laminated sediments. Using this approach, it is possible to select a group of lakes that have a high probability of having laminated sediments, which can maximize fieldwork efficiency. Morphological variables largely control only the deposition of biogenic laminae, and thus may not be applicable to identify lakes with clastic or clastic-organic laminations, for which catchment geology and hydrology are also of major importance.

Our results illustrate that northeast Poland, a region recognized as ideal for study of European climate variability, has many potentially promising lacustrine sediment archives. Laminations and high sedimentation rates offer the potential for high-resolution, quantitative reconstruction of climate changes, applying a range of biological, isotopic and geochemical proxies. With regard to the occurrence of laminated lake sediments, northeast Poland should be a prime focus area for investigating past climate and environmental change in Europe.

Acknowledgments Field and laboratory research was supported by a Polish Ministry of Science and Education grant to WT (N N306 275635). Excellent field assistance by colleagues and students from the Department of Geomorphology and Quaternary Geology (University of Gdańsk) is greatly appreciated. We thank two anonymous reviewers and Mark Brenner for their invaluable comments. This is a contribution to the bilateral scientific program "Northern Polish Lake Research" (NORPOLAR), a Polish-German research initiative funded by the Deutsche Forschungsgemeinschaft and the Polish Ministry of Science and Education.

Open Access This article is distributed under the terms of the Creative Commons Attribution License which permits any use, distribution, and reproduction in any medium, provided the original author(s) and the source are credited.

\section{References}

Anderson RY, Dean WE, Bradbury JP, Love D (1985) Meromictic lakes and varved lake sediments in North America. US Geol Surv Bull 1607:1-19

Ariztegui D, Anselmetti FS, Robbiani JM, Bernasconi SM, Brati E, Gilli A, Lehmann MF (2010) Natural and humaninduced environmental change in southern Albania for the last 300 years-constraints from the Lake Butrint sedimentary record. Glob Planet Change 71:183-192
Brauer A (2004) Annually laminated lake sediments and their palaeoclimatic relevance. In: Fischer H, Kumke T, Lohmann $G$ (eds) The climate in historical times. Towards a synthesis of Holocene proxy data and climate models. Springer Verlag, pp 109-128

Brauer A, Casanova J (2001) Chronology and depositional processes of the laminated sediment record from Lac d'Annecy, French Alps. J Paleolimnol 25:163-177

Brauer A, Endres C, Negendank JFW (1999) Lateglacial calendar year chronology based on annually laminated sediments from Lake Meerfelder Maar, Germany. Quatern Int 61:17-25

Choiński A (2008) Limnologia fizyczna Polski. Wydawnictwo Naukowe UAM, Poznań

Cooper MC, O'Sullivan PE (1998) The laminated sediments of Loch Ness, Scotland: preliminary report on the construction of a chronology of sedimentation and its potential use in assessing Holocene climatic variability. Palaeogeogr Palaeoclimatol Palaeoecol 140:23-31

Corella JP, Moreno A, Morellón M, Valenti R, Giralt S, Rico MT, Pérez-Sanz A, Valero-Garcés BL (2011) Climate and human impact on a meromictic lake during the last 6,000 years (Montcortés Lake, Central Pyrenees, Spain). J Paleolimnol 46:351-367

Croudace IW, Rindby A, Rothwell RG (2006) ITRAX: description and evaluation of a new multi-function X-ray core scanner In: Rothwell RG (ed) New techniques in sediment core analysis. Geological Society, London, Special Publications 267, pp 51-63

Czymzik M, Dulski P, Plessen B, von Grafenstein U, Naumann R, Brauer A (2010) A 450 year record of spring-summer flood layers in annually laminated sediments from Lake Ammersee (southern Germany). Water Resour Res 46:W11528

Dörfler W, Feeser I, van den Bogaard C, Dreibrodt S, Erlenkeuser H, Kleinmann A, Merkt J, Wiethold J (2012) A high-quality annually laminated sequence from Lake Belau, Northern Germany: revised chronology and its implications for palynological and tephrochronological studies. Holocene 22:1413-1426

Dreibrodt S, Bork HR, Negendank JFW (2002) Laminierte Oberflächensedimente im Woseriner See (Mecklenburg). Greifswalder Geographische Arbeiten 26:107-110

Enters D, Kirchner G, Zolitschka B (2006) Establishing a chronology for lacustrine sediments using a multiple dating approach. A case study from the Frickenhauser See, central Germany. Quat Geochronol 1:249-260

Eusterhues K, Lechterbeck J, Schneider J, Wolf-Brozio U (2002) Late- and Post-Glacial evolution of Lake Steisslingen (I): sedimentary history, palynological record and inorganic geochemical indicators. Palaeogeogr Palaeoclimatol Palaeoecol 187:341-371

Guyard H, Chapron E, St-Onge G, Anselmetti FS, Arnaud F, Magand O, Francus P, Méliéres M-A (2007) High-altitude varve records of abrupt environmental changes and mining activity over the last 4000 years in the Western French Alps (Lake Bramant, Grandes Rousses Massif). Quat Sci Rev 26:2644-2660

Hambley GW, Lamoureux SF (2006) Recent summer climate recorded in complex varved sediments. Nicolay Lake, Cornwall Island, Nunavut, J Paleolimnol 35:629-640 
Hausmann S, Lotter AF, van Leeuwen JFN, Ohlendorf C, Lemcke G, Grönlund E, Sturm M (2002) Interactions of climate and land use documented in the varved sediments of Seebergsee in the Swiss Alps. Holocene 12:279-289

Jańczak J (1999) Atlas jezior Polski. Tom III, Bogucki Wydawnictwo Naukowe, Poznań

Kinder M, Tylmann W, Enters D, Piotrowska N, Poręba G, Zolitschka B (2013) Construction and validation of calendar-year time scale for annually laminated sedimentsan example from Lake Szurpiły (NE Poland). GFF. doi:10. 1080/11035897.2013.785015

Larocque-Tobler I, Grosjean M, Heiri O, Trachsel M, Kamenik C (2010) Thousand years of climate change reconstructed from chironomid subfossils preserved in varved lake Silvaplana, Engadine, Switzerland. Quat Sci Rev 29:1940-1949

Larsen CPS, MacDonald GM (1993) Lake morphometry, sediment mixing and the selection of sites for fine resolution palaeoecological studies. Quat Sci Rev 12:781-792

Larsen CPS, Pienitz R, Smol JP, Moser KA, Cumming BF, Blais JM, MacDonald GM, Hall RI (1998) Relations between lake morphometry and the presence of laminated lake sediments: a re-examination of Larsen and MacDonald (1993). Quat Sci Rev 17:711-717

Leemann A, Niessen F (1994) Varve formation and climatic record in an Alpine proglacial lake: calibrating annuallylaminated sediments against hydrological and meteorological data. Holocene 4:1-8

Lepš J, Šmilauer P (2003) Multivariate analysis of ecological data using CANOCO. Cambridge University Press, Cambridge

Lotter AF (1989) Evidence of annual layering in Holocene sediments of Soppensee, Switzerland. Aquat Sci 51:19-30

Lotter AF, Lemcke G (1999) Methods for preparing and counting biochemical varves. Boreas 28:243-252

Lotter AF, Sturm M, Teranes JL, Wehrli B (1997) Varve formation since 1885 and high-resolution varve analyses in hypertrophic Baldeggersee (Switzerland). Aquat Sci 59:304-325

Lüder B, Kirchner G, Lücke A, Zolitschka B (2006) Palaeoenvironmental reconstructions based on geochemical parameters from annually laminated sediments of Sacrower See (northeastern Germany) since the 17th century. J Paleolimnol 35:897-912

Luterbacher J, Xoplaki E, Küttel M, Zorita E, González-Rouco JF, Jones PD, Stössel M, Rutishauser T, Wanner H, Wibig J, Przybylak R (2010) Climate change in Poland in the past centuries and its relationship to European climate: evidence from reconstructions and coupled climate models. In: Przybylak R, Majorowicz J, Brázdil R, Kejna M (eds) The Polish climate in the European context: an historical overview. Springer Verlag, pp 3-39

Marszelewski W (2005) Zmiany warunków abiotycznych w jeziorach Polski Północno-Wschodniej. Nicolaus Copernicus University Press, Torun

Martín-Puertas C, Valero-Garcés BL, Brauer A, Mata MP, Delgado-Huertas A, Dulski P (2009) The Iberian-Roman Humid Period (2600-1600 cal yr BP) in the Zoñar Lake varve record (Andalucía, southern Spain). Quat Res 71:108-120

Merkt J, Müller H (1999) Varve chronology and palynology of the Lateglacial in Northwest Germany from lacustrine sediments of Hämelsee in Lower Saxony. Quat Int 61:41-59
Ojala AEK, Alenius T (2005) 10000 years of interannual sedimentation recorded in the Lake Nautajärvi (Finland) clastic-organic varves. Palaeogeogr Palaeoclimatol Palaeoecol 219:285-302

Ojala AEK, Saarinen T, Salonen VP (2000) Preconditions for the formation of annually laminated lake sediments in southern and central Finland. Boreal Environ Res 5:243-255

Ojala AEK, Francus P, Zolitschka B, Besonen M, Lamoureux SF (2012) Characteristics of sedimentary varve chronologies-A review. Quat Sci Rev 43:45-60

O'Sullivan PE (1983) Annually-laminated lake sediments and the study of Quaternary environmental changes. Quat Sci Rev 1:245-313

Peglar SM, Fritz SC, Alapieti T, Saarnisto M, Birks HJB (1984) Composition and formation of laminated sediments in Diss Mere, Norfolk, England. Boreas 13:13-28

Petterson G (1996) Varved sediments in Sweden: a brief review. In: Kemp AES (ed) Palaeoclimatology and palaeoceanography from laminated sediments. Geol Soc Spec Publ 116 , pp. $73-77$

Przybylak R (2010) Instrumental Observations. In: Przybylak R, Majorowicz J, Brázdil R, Kejna M (eds) The Polish climate in the European context: an historical overview. Springer Verlag, pp 129-166

Ralska-Jasiewiczowa M, Goslar T, Madeyska T, Starkel L (eds) (1998) Lake Gościąż, central Poland. A monographic study. W. Szafer Institute of Botany, Kraków

Randsalu Wendrup L, Conley D, Carstensen J, Snowball I, Jessen C, Fritz S (2012) Ecological regime shifts in Lake Kälksjön, Sweden, in response to abrupt climate change around the 8.2 ka cooling event. Ecosystems 15:1336-1350

Renberg I (1981) Formation, structure and visual appearance of iron-rich, varved lake sediments. Int Ver Theor Angew Limnol Verh 21:94-101

Renberg I, Segerström U (1981) Application of varved lake sediments in paleoenvironmental studies. Wahlenbergia 7:125-133

Romero-Viana L, Juliá R, Camacho A, Vicente E, Miracle MR (2008) Climate signal in varve thickness: lake La Cruz (Spain), a case study. J Paleolimnol 40:703-714

Saarnisto M (1986) Annually laminated lake sediments. In: Berglund BE (ed) Handbook of Holocene palaeoecology and palaeohydrology. Wiley, Chichester and New York, pp 343-370

Schmidt R, van den Bogaard C, Merkt J, Müller J (2002) A new Lateglacial chronostratigraphic tephra marker for the south-eastern Alps: the Neapolitan Yellow Tuff (NYT) in Langsee (Austria) in the context of a regional biostratigraphy and palaeoclimate. Quat Int 88:45-56

Simola HLK (1979) Micro-stratigraphy of sediment laminations deposited in a chemically stratifying eutrophic lake during the years 1913-1976. Holarctic Ecol 2:160-168

Simola HLK, Coard MA, O'Sullivan PE (1981) Annual laminations in the sediments of Loe Pool, Cornwall. Nature 290:38-238

Stebich M, Brüchmann C, Kulbe T, Negendank JFW (2005) Vegetation history, human impact and climate change during the last 700 years recorded in annually laminated sediments of Lac Pavin, France. Rev Palaeobot Palynol 133:115-133 
Tomkins JD, Lamoureux SF, Sauchyn DJ (2008) Reconstruction of climate and glacial history based on a comparison of varve and tree-ring records from Mirror Lake, Northwest Territories, Canada. Quat Sci Rev 27:1426-1441

Tomkins JD, Lamoureux SF, Antoniades D, Vincent WF (2009) Sedimentology of perennial ice-covered, meromictic Lake A, Ellesmere Island, at the northern extreme of Canada. Can J Earth Sci 46:83-100

Trachsel M, Grosjean M, Schnyder D, Kamenik C, Rein B (2010) Scanning reflectance spectroscopy (380-730 nm): a novel method for quantitative high-resolution climate reconstructions from minerogenic lake sediments. J Paleolimnol 44:979-994

Tylmann W (2007) Pobór i opróbowanie nieskonsolidowanych, silnie uwodnionych osadów jeziornych o nienaruszonej strukturze-uwagi metodyczne i stosowany sprzęt. Przegląd Geologiczny 55:151-156

Tylmann W, Woźniak PP, Czarnecka K, Jaźwiecka M (2006) New sites with laminated lake sediments in north-eastern Poland: preliminary results of field survey. Limnol Review 6:283-288

Tylmann W, Szpakowska K, Ohlendorf C, Woszczyk M, Zolitschka B (2012) Conditions for deposition of annually laminated sediments in small meromictic lakes: a case study of Lake Suminko (northern Poland). J Paleolimnol 47:55-70

Tylmann W, Enters D, Kinder M, Moska P, Ohlendorf C, Poręba G, Zolitschka B (2013) Multiple dating of varved sediments from Lake Łazduny, northern Poland: toward an improved chronology for the last 150 years. Quat Geochronol 15:98-107

Veski S, Seppä H, Ojala AEK (2004) Cold event at 8200 years ago recorded in annually laminated lake sediments in Eastern Europe. Geology 32:681-684
Wacnik A (2009) Vegetation development in the Lake Miłkowskie area, north-eastern Poland, from the Plenivistulian to the late Holocene. Acta Paleobotanica 49:287-335

Więckowski K (1978) Bottom deposits in lakes of different regions of Poland (their characteristics, thickness and rates of accumulation). Pol Arch Hydrobiol 25:483-489

Wolff C, Brauer A, Nomade J, DecLakes Participants (2006) Varve chronology of the last 3000 years of the sediment record from Lake Mondsee (Upper Austria). In: Geophysical Research Abstracts 8. European Geosciences Union, Vienna, p 06750

Zielski A, Krąpiec M, Koprowski M (2010) Dendrochronological Data. In: Majorowicz J, Brázdil R, Kejna M (eds) Przybylak R. The Polish Climate in the European Context, An Historical Overview. Springer Verlag, pp 191-217

Zillén L, Snowball I, Sandgren P, Stanton T (2003) Occurrence of varved lake sediment sequences in Värmland, west central Sweden: lake characteristics, varve chronology and AMS radiocarbon dating. Boreas 32:612-626

Zolitschka B (2007) Varved lake sediments. In: Elias SA (ed) Encyclopedia of Quaternary Science. Elsevier, Amsterdam, pp 3105-3114

Zolitschka B, Brauer A, Negendank JFW, Stockhausen H, Lang A (2000) Annually dated late Weichselian continental paleoclimate record from the Eifel, Germany. Geology 28:783-786

Zolitschka B, Mingram J, van der Gaast S, Jansen JHF, Naumann R (2001) Sediment logging techniques. In: Last WM, Smol JP (eds) Tracking environmental change using lake sediments, vol 1., Basin Analysis, Coring, and Chronological Techniques Kluwer Academic Publishers, Dordrecht, pp 137-153 